Landscape Online | Volume 68 | 2019 | Pages 1-18 | DOI 10.3097/LO.201968

Submitted: 27 November 2018 | Accepted in revised version: 12 May 2019| Published: 18 May 2019

\title{
Tourists' Preferences for Alpine Pastures Maintenance
}

\begin{abstract}
Traditional extensive agriculture is the main factor of landscape management in the mountains: a large part of the Alps is modelled by agriculture. Interpreted as a multifunctional activity, including landscape modelling and maintenance, agriculture generates the conditions under which mountain pasture landscape is an economic resource potentially exploitable by tourism. The aim of this work is to draw the profiles of tourists of mountain pastures and to estimate their Willingness to Pay (WTP) for landscape pastures resilience. The innovation of this work lies in the use of a multivariate approach using Contingent Valuation Method (CVM), Multiple Correspondence Analysis (MCA) and Hierarchical Cluster Analysis (HCA). The analysis obtained three clusters that identify different tourists' profiles. The main result is the existence of a positiveWTP for the permanence of pasture systems with an agricultural management. Policy guidelines have been proposed to institutions owning pastures and huts to manage these assets.
\end{abstract}

\section{Keywords:}

landscape management, pastures resilience, mountain, Contingent Valuation Method, Multiple Correspondence Analysis, Cluster analysis

\author{
Chiara Mazzocchi ${ }^{1 *}$, Guido Sali ${ }^{1}$, \\ Giordano Ruggeri ${ }^{1}$ \\ ${ }^{1)}$ University of Milan, Italy \\ *Corresponding author: Chiara \\ Mazzocchi, University of Milan, Via \\ Celoria 2, 20133, Milan, Italy. \\ Email: chiara.mazzocchi1@unimi.it
}




\section{Introduction}

The evolution of the demand for agricultural products requires new services to be provided by the primary sector, which is typical of a multifunctional approach (Streifeneder et al. 2007, Lamarque \& Lambin 2015, Torquati et al. 2017), from environmental services to biodiversity (Bernuès et al. 2015), from heritage to landscape conservation (Gios et al. 2006).

Interpreting agriculture as landscape construction, care for biodiversity and maintenance of traditions and knowledgerequires the exploitation of these assets through tourism, sports and education that may enhance rural economies (Mazzocchi \& Sali 2016, Van Der Ploeg et al. 2008). Thus, tourism has acquired a central position in the debate on the future of rural, upland and mountain economies across Europe, especially in the light of both the increasing recognition of these services and functions (Lee et al. 2010) and the demand for the natural environment and landscape (Castellani \& Sala 2009, Europarc 1995). According to Lane (1994), rural areas are constantly evolving, and different forms of rural tourism have developed in several regions with different intensity. More in detail, "Rural tourism is a complex multi-faceted activity: it is not just farmbased tourism. It includes farm-based holidays but also special-interest nature holidays and ecotourism, walking, climbing and riding holidays, adventure, sport and health tourism, hunting and angling, educational travel, arts and heritage tourism, and, in some areas, ethnic tourism." (Lane 1994, pp.9)

Since rural tourists' need to be in contact with nature is spreading (Strobl et al. 2015), a relaxing time to spend with family is more and more requested (Lane 1994), the search of a sustainable way to spend holidays is increasing (Millàn Vàzquez De La Torre et al. 2013) and rural areas can take advantage of this market niche to generate additional income. Moreover, as rural areas often depend economically on the income generated by theprimary sector, rural tourism allows to diversify the sources of income and to get more stable economic systems (MillànVàzquez De La Torre et al. 2013).
One of the most important aspects in rural tourism is consumer demand (Bramwell, 1994), and it seems obvious that management decisions of rural areas should consider consumers' needs. According to Jindrová \& Dömeová (2013), customer satisfaction is the basis for the growth of rural tourism in recent years, as tourism represent a new source of income and employment, promoting the economic revitalization of depressed rural areas (Molera\&Pilar Albaladejo 2007, Sala \& Castellani 2009). Among the most investigated aspects by research dealing with rural areas there are tourists' motivations and preferences for visiting rural places (Molera\&Pilar Albaladejo 2007, MillànVàzquez De La Torre et al. 2013, Bel et al. 2015). The motivations that drive tourists are mainly related to be in contact with nature, to enjoy landscape and fresh air (Hjalager et al. 2017) and to make outdoor activities (Hjalager et al. 2017, MillànVàzquez De La Torre et al. 2013). In addition, the development of "active tourism" in rural areas, i.e. tourism linked to outdoor activities, took place mainly in protected areas or in destinations branded as unique (Bel et al. 2015). Billore (2018) highlights the importance and the rising consumption of cultural proposals in rural areas, often linked to the historical heritage and services of the territory. Other authors (Chrysocou et al. 2006, Devesa et al. 2010) stress the importance of gastronomy offers on the territory, together with hospitality and lodging availability that are important drivers of tourists' staying in rural contexts. Moreover, Bel et al. (2015) find that gastronomic tourism has been shown to attract higher-spending tourists and its link to local products and amenities should be fostered to develop rural tourism. The quality of services offered to tourists in rural areas is investigated by Chin \& Lo (2017): their findings show that environmental factors are among the main concerns for visitors, and support from local communities serves as an additional advantage to attract tourists. That is, the development of the destination must be led by the aim of sustainable development and attentive conservation practices to protect the natural resources.

Mountain rural tourism can be considered a branch of rural tourism, according to the rurality characterising a part of mountain regions. Moreover, in these areas 
agriculture generates the conditions under which mountain region can serve as an economic resource potentially exploitable by tourism. According to Soliva et al. (2008), low intensive farming systems generate extensive green areas, such as meadows and pastures.

Few studies focus on the relationship between the characteristics of tourists and their WTP for services, particularly in the mountains. In many cases a Contingent Valuation Method (CVM) approach is used, often applied to estimate the value visitors place on recreation by measuring visitor consumer surplus and WTP for non-consumptive uses, but also Conjoint Analysys (Marangon et al. 2013) and Choice Experiments method (Mazzocchi \& Sali 2018, Goio \& Gios 2012, Thiene \& Scarpa 2008). As an example, Keske \& Mayer (2014) tried to estimate the WTP of tourists for hypothetical fee increases at hiking trails located in a mountain area in Colorado State, USA, using a Contingent Valuation Method approach. Molina et al. (2016) propose an integrated evaluation of landscape value using both CVM and Geographical Information System, administering a questionnaire to tourists in a rural area of Spain. Marangon et al. (2013) develop a conjoint analysis on a mountain rural area called Natisone Valley, in Italy, to find that the main attributes influencing tourists staying in this area are the availability of information facilities (as guided tours) and transport means.

At the same time, several studies have attempted to define tourists' profiles using market segmentation techniques to define groups of tourists with similar preferences (Bel et al. 2015, Lima et al. 2012, Wedel \& Kamakura 1998) and to improve the offer of mountain tourism. As an example, Strobl et al. (2015) investigate the ecotourism demand of mountain tourists, defined as responsible travel to natural areas that conserves the environment and improves the well-being of local people (The International Ecotourism Society 2006), interpreted as a specific segment of rural tourism. One of the main results is that mountain tourists show similarities in travel motives to eco-tourists, suggesting that they are sensitive to ecological concerns. Lima et al. (2012), identify different clusters of visitors, in a Portuguese mountain destination, according to the level and patterns of visitors'expenditure during the visit.
Although previous research addressed the topic of mountain tourists' profiles and their WTP for landscape conservation, services development and other characteristics, none of the published researcheshave focused on tourists' preferencesfor mountain pastures and landscape maintenance, nor any of them used the mixed approach of WTP elicitation and segmentation of tourists alltogether. The aim of the paper is to analyse the characteristics of potential tourists of a mountain area, to estimate their sensitivity to the issues related to pastures and landscape conservationand to elicit their WTP for pastures maintenance. The results show three different clusters described by several variables linked to the main issue of mountain pastures resilience. Moreover, the results include the WTP for pastures maintenance of each cluster, allowing to draw some suggestions to public institutions to better manage their owned pastures properties and to efficiently target their investments.

Themethodologyincludes threesteps:WTPelicitation by using CVM, the Multiple Correspondence Analysis (MCA), and the Hierarchical Cluster Analysis (HCA).

Section two describes the methodology, the data and the modelling procedure. Section three presents the results, which are discussed in section four. Finally, section five illustrates the conclusions.

\section{Methodology}

\subsection{Case study, data and questionnaire}

The questionnaire was prepared using closed-ended questions to allow for an easier categorization. The first part of the questionnaire began with an introduction about mountain pastures and upland farms issues, followed by a description of the research aim. The introduction was focused on the description of pastures context insome Italian municipalities ${ }^{1}$ of the Seriana, Brembana and Scalve

\footnotetext{
1 The huts and pastures described in the questionnaire refer to the municipality of Valbondione, Gromo, Oltressenda Alta, Valnegra, Vedeseta,Taleggio and Colere
} 


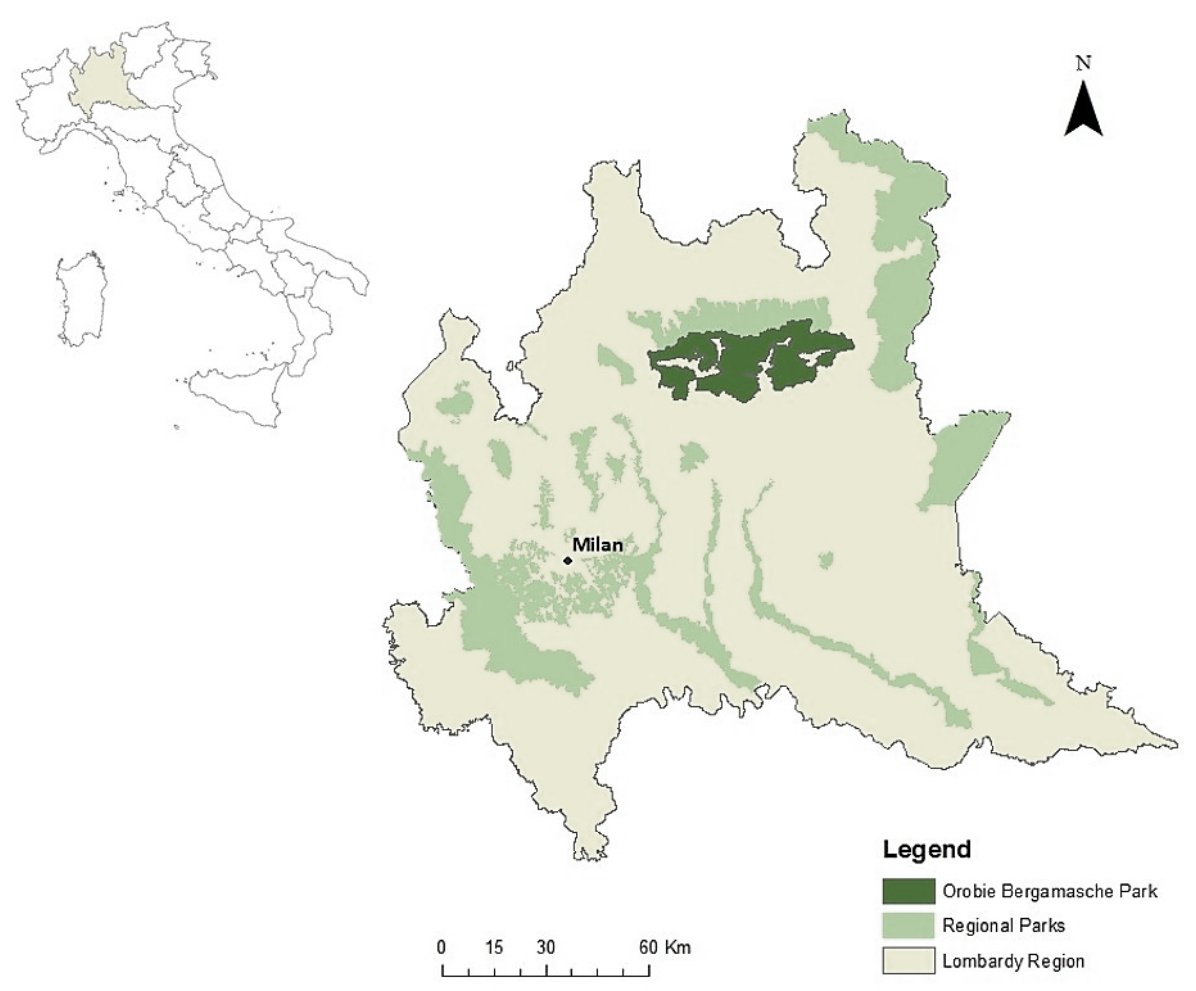

Figure 1: Orobie Bergamasche Regional Park, in Lombardy region.

Valley, located within the Regional Park of Orobie Bergamasche Alps, in the northern area of the Province of Bergamo, in Lombardy Region (Figure 1)

In the Park there are 118 mountain huts, the highest concentration is in the Brembana Valley. Seriana and Scalve Valleys show an average pastureland surface that is greater than that of the Val Brembana (Baronchelli 2016). The area is rich in endemic species and biodiversity characterized by open areas with herbaceous vegetation, such as grassland and dry meadows, in addition to rocky areas placed at higher altitudes. Since pastures property is public, local municipalities are interested in knowing public opinion about the use of these areas and the type of investment that they should do to keep them active, given both the difficulty for farming' activities and the related abandonment of huts.Many of the pastures are publicly owned and are rented to privates. In the first part of the questionnaire subjects were asked to express their opinion, on a scale from 1 to 5 , about the importance of the environment, territory, accessibility and activity of pastures (Table 1 ).

In the second part of the questionnaire, WTP is made elicited using the double bounded CVM. The third part of the questionnaire addresses the personal characteristics of the respondents.
Using "Survey Monkey", an online platform for submitting surveys, the questionnaires have been distributed online. By publishing the link of the questionnaire on Facebook, followed by a description of various Facebook "groups", the sample was selected. The questionnaire has been spread in groups where users could potentially be interested in the topic of the research, such as the pages of the trekking lovers, of the Alpine Huts and mountaineers to reach tourists mainly coming from the Lombardy region. This procedure has been chosen to reasonably select subjects on the basis of a voluntary interest and not due to the insistence of an interviewer. The choice of on-line interviews has been made to have a large population sample who had never seen before the questionnaire or heard about it before, as at the contrary happens for the focus groups, to pose the proposed issue without influencing in any way the interviewed sample. In fact, the aim of the analysis was to collect data from a population of tourists without any contact before, to have a more direct responses, with no intermediation.

\subsection{Conceptual framework and modelling}

The methodological approach presents three steps: WTP elicitation (2.2.1), MCA (2.2.2), and HCA (2.2.3). 
Table 1: Structure of the survey.

\begin{tabular}{|c|c|c|c|c|}
\hline Question & Variables Name & Definition & Modality & Measure Unit \\
\hline \multirow{6}{*}{1} & ACCOM & Presence of accommodations in the valley & \multirow{6}{*}{ Score } & \multirow{6}{*}{ From 1 to 5} \\
\hline & ENV & Environment unpolluted & & \\
\hline & TOWN & Well preserved villages & & \\
\hline & MULT & Presence of multifunctional farms in the valley & & \\
\hline & INFR & Infrastructural equipment & & \\
\hline & EVE & Number of touristic events in the valley & & \\
\hline \multirow{5}{*}{2} & WATER & Importance of farms in water management & \multirow{5}{*}{ Score } & \multirow{5}{*}{ From 1 to 5} \\
\hline & RISK & $\begin{array}{c}\text { Agriculture importance in reduction of } \\
\text { hydrogeological risk }\end{array}$ & & \\
\hline & EMPLOY & Job preservation by agriculture & & \\
\hline & BIOD & Biodiversity conservation by agriculture & & \\
\hline & HERIT & Heritage preservation by agriculture & & \\
\hline \multirow{3}{*}{3} & AGRICULTURE & Agro-productive orientation of pastures & \multirow{3}{*}{$\begin{array}{c}\text { Alternati } \\
\text { ve } \\
\text { (choice) }\end{array}$} & \multirow{3}{*}{ 0: no 1: yes } \\
\hline & TOURISM & Touristic orientation of pastures & & \\
\hline & ACTUAL & Maintenance of actual situation of pastures & & \\
\hline \multirow{3}{*}{4} & PASTURE & $\begin{array}{l}\text { Preference for pasture increase and forest } \\
\text { decrease }\end{array}$ & \multirow{3}{*}{$\begin{array}{l}\text { Alternati } \\
\text { ve }\end{array}$} & \multirow{3}{*}{ 0: no 1: yes } \\
\hline & FOREST & $\begin{array}{l}\text { Preference for pasture decrease and forest } \\
\text { increase }\end{array}$ & & \\
\hline & ACTUAL & Preference for actual situation & & \\
\hline \multirow{4}{*}{5} & NONE & I would like no particular service in the pasture & \multirow{4}{*}{$\begin{array}{l}\text { Multiple } \\
\text { (choice) }\end{array}$} & \multirow{4}{*}{ 0: no 1: yes } \\
\hline & SELL & I would like agricultural products selling & & \\
\hline & RIST & I would like food service & & \\
\hline & BED & I would like accommodation service & & \\
\hline \multirow{3}{*}{6} & PATH & Preference for accessibility pasture by path & \multirow{3}{*}{$\begin{array}{l}\text { Alternati } \\
\text { ve }\end{array}$} & \multirow{3}{*}{ 0: no 1: yes } \\
\hline & ROAD & Preference for accessibility pasture by road & & \\
\hline & TRAIL & Preference for accessibility pasture by trail & & \\
\hline 7 & WTP & $\begin{array}{l}\text { Willingness to pay for the permanence of pastures } \\
\text { a) } 30,60,15 \text {; b) } 50,100,20 \text {; c) } 80,150,40 \text {; d) } 100 \text {, } \\
200,50\end{array}$ & $\begin{array}{l}\text { Double } \\
\text { bounded }\end{array}$ & $€$ \\
\hline 8 & INFO & $\begin{array}{l}\text { Information degree about the issue of } \\
\text { questionnaire }\end{array}$ & Score & From 1 to 5 \\
\hline 9 & INCOME & Family income per month & $\begin{array}{l}\text { Quantita } \\
\text { tive }\end{array}$ & $0-\infty$ \\
\hline 10 & AGE & Age & $\begin{array}{l}\text { Quantita } \\
\text { tive }\end{array}$ & $0-\infty$ \\
\hline 11 & FEM & Gender & $\begin{array}{l}\text { Alternati } \\
\text { ve }\end{array}$ & 0: no 1: yes \\
\hline 12 & FAM & Number of family components & $\begin{array}{l}\text { Quantita } \\
\text { tive }\end{array}$ & $0-\infty$ \\
\hline 13 & CHILD & Number of children under 18 years & $\begin{array}{l}\text { Quantita } \\
\text { tive }\end{array}$ & $0-\infty$ \\
\hline 14 & $\begin{array}{l}\text { MIDDLE } \\
\text { SCHOOL }\end{array}$ & Lower secondary school diploma & $\begin{array}{l}\text { Alternati } \\
\text { ve }\end{array}$ & $0:$ no 1: yes \\
\hline 15 & HIGHSCHOOL & High school diploma & $\begin{array}{l}\text { Alternati } \\
\text { ve }\end{array}$ & 0: no 1: yes \\
\hline 16 & DEGREE & Degree certificate & $\begin{array}{l}\text { Alternati } \\
\text { ve }\end{array}$ & 0: no 1: yes \\
\hline
\end{tabular}




\subsubsection{The WTP elicitation}

The CVM is the most widely used model for estimating non-market values, eliciting consumer preferences and WTP (Rathnayake 2016) for goods and services that are not directly traded in the market, such as landscapes value, ecosystems services, ecological functions, and so on. In few cases, CVM has been used to assess the permanence of mountain farms. In the present study, a CVM was used to elicit respondents' WTP for the conservation of mountain pastures and landscapes. The WTP was directly elicited from individual $i$ after applying a contingent valuation questionnaire using the dichotomous choice model, generating a dichotomous answer $\left(y_{i}=\right.$ 0 if the individual answers no and $y_{i}=1$ if the answer is yes) to a question about paying a previously determined amount $\mathrm{s}_{\mathrm{i}}$, which randomly varies across individuals (Lopez 2012). We have obtained four group of individuals according to the four amounts of money proposed: the yes-yes, the yes-no, the noyes, the no-no groups (Table 3 ). In fact, if individuals answered "yes" to the first question, then they were asked about their WTP for a higher amount. If they answered "no" to the first question, a lower amount is offered. So, in the second question, the amount asked depends on the answer to the first question. This method, called"double bounded" model, allows to obtain two answers per each respondent, introducing the identification of two limits, lower and upper, in which the individual WTP is located. To determine the average WTP of the survey sample, different models were examined to identify the best fitting model, using the Likelihood Ratio Test (LRT). The differences between the log-likelihood in the different models correspond to the ratio between the likelihoods. Covariates are respondents'age (AGE), gender (FEM), number of family members (FAM), number of children per family (CHILD), the respondents' school level (MED, HIGH, DEGR), the family income per month (INCOME), and the best combinations between them. The introduction of covariates leads to an improvement of the basic model without covariates, tested through the likelihood ratio test (LRT), leading to the best fitting model that is the one with two covariates, Model 10. Model 10 estimates an average WTP value of 56.34 $€$ and includes two individual-specific variables: „INCOME“ and „FAM“ (Table 2).

Thus, in the MCA analysis, the average WTP value resulted from the WTP assessment has been used to find the individual WTP per respondent.

The average WTP of Model 10, that is $56.39 €$, was used to calculate the individual WTP per respondent. The individual WTP was calculated as follows:

WTP $=\beta_{0}+\beta_{1}^{*} x_{1}+\beta_{2}^{*} x_{2}$

where $x_{1}$ is the variable INCOME, $x_{2}$ is the variable FAM, and $\beta$ is the $\beta$ coefficient of the model, $\beta_{x 1}$ is the $\beta$ coefficient of the variable INCOME in the model, and $\beta_{x 2}$ is the $\beta$ coefficient of the variable FAM.

Table 2: WTP models.

\begin{tabular}{|c|c|c|c|c|c|c|c|c|c|c|c|}
\hline & $\begin{array}{ll}\text { Model } & 1 \\
\text { (nocov) } & \end{array}$ & Model 2 & Model 3 & Model 4 & Model 5 & Model 6 & Model 7 & Model 8 & Model 9 & Model 10 & Model 11 \\
\hline $\mathrm{n}^{\circ}$ observations & 401.00 & 370.00 & 370.00 & 367.00 & 367.00 & 370.00 & 370.00 & 370.00 & 370.00 & 367.00 & 365.00 \\
\hline$\beta$ coeff & 53.78 & 55.89 & 56.33 & 57.88 & 55.88 & 59.59 & 56.45 & 52.42 & 32.92 & 35.17 & 34.31 \\
\hline AGE & & 0.01 & & & & & & & & & \\
\hline FEM & & & -0.25 & & & & & & & & \\
\hline FAM & & & & -0.43 & & & & & & -0.99 & -0.86 \\
\hline CHILD & & & & & 0.83 & & & & & & -0.15 \\
\hline SCHOOL -med & & & & & & -13.86 & & & & & \\
\hline SCHOOL -high & & & & & & & -0.54 & & & & \\
\hline SCHOOL -degr & & & & & & & & 12.86 & & & \\
\hline INCOME & & & & & & & & & 0.01 & 0.01 & 0.01 \\
\hline WTP & 53.78 & 56.20 & 56.20 & 56.47 & 56.24 & 56.15 & 56.20 & 56.20 & 56.08 & 56.39 & 56.14 \\
\hline Log likelihood & -545.57 & -507.20 & -507.20 & -502.59 & -502.71 & -506.08 & -507.19 & -506.10 & -502.78 & -497.79 & -494.56 \\
\hline$\Delta$ Log likelihoodmod 1 & & 76.74 & 76.74 & 85.96 & 85.72 & 78.98 & 76.76 & 78.94 & 85.58 & 95.56 & 102.02 \\
\hline$\Delta$ Log likelihoodmod $10 / 4$ & & & & & & & & & & 9.60 & \\
\hline$\Delta$ Log likelihoodmod $11 / 10$ & & & & & & & & & & & 6.46 \\
\hline
\end{tabular}




\subsubsection{The MCA}

As an extension of Correspondence Analysis with more than two variables and a generalization of the principal component analysis with categorical instead of quantitative variables (Abdi \& Valentin 2007), MCA searches for the relationships pattern of several categorical variables that reveal concealed patterning in complex datasets. MCA enables the representation and modelling of complex datasets as clouds of points in a multidimensional Euclidean space; the results are therefore interpreted based on the relative positions of the points and their distributions along the dimensions, and more category frequencies show similar distributions the closer they are represented in space (Greenacre \& Hastie 1997, Johnson \& Wichern 2007). The variables used to perform MCA were selected from the variables included in the questionnaire to maximize the explained variance while retaining the main relevant issues evaluated in the survey. Variables with low component loadings were sequentially excluded from the analysis. A solution with seven variables was selected as a fair compromise between the readability of the results and the maximization of the explained variance based on the first two axes.

\subsubsection{Hierarchical Cluster analysis}

Cluster analysis following MCA is often used to classify individuals into homogeneous groups; in this case, the clusters are derived from the MCA dimension object scores, which are based on the quantification of the qualitative variables that define the individual profile. Hierarchical classification was performed using Ward's aggregation, a hierarchical classification algorithm. Ward's minimum variance criterion minimizes the total within-cluster variance, while maximizing the variance between classes, and groups are formed to minimize the pooled withingroup sum of squares. These inertias are calculated from the coordinates of the elements on the factorial plane of the MCA. HCA is performed using the principal components of the factorial analysis, and the hierarchy is represented using a dendrogram. The vertical axis of the dendrogram represents the distance or dissimilarity between clusters, and the horizontal axis represents the objects and clusters.

\section{Results}

\subsection{Descriptive statistics of the sample}

Respondents are 37 years old on average (Table 3 ) and equally distributed between males and females.

The average number of children and young people under 18 years of age (CHILD) per family is less than 1 because the sample includes a wide age range from 18 to 72 years; therefore, young people without children or younger brothers or sisters and other elderly people with adult children were also included. The median household income is approximately $1,950 €$, precisely the central range of the incomes proposed in the questionnaire.

In terms of education, most of the sample has a high school diploma (45\%), while the remaining individuals comprise people with a low school level (22\%) and those with a higher school level, i.e., a degree (27\%).

Most respondents assign maximum importance (level 5) to the presence of an uncontaminated environment (55.24\%) and well-preserved historic villages (56\%) in the municipalities hosting the mountain pastures. The accommodations and infrastructure of the municipality of the valley showed the highest importance for, respectively, $35.43 \%$ and $40.33 \%$ of the sample, similar to the presence of multifunctional farms (40.33\%).

Concerning the second question, which is related to the importance of farms performing various functions, biodiversity and heritage conservation and enhancement of employment have the highest score (level 5) for $41 \%$ of the sample. The variables related to risk management and water are evaluated by $50 \%$ of the population, revealing medium importance ( 3 and 4 level). Question 4 provides an interpretation of what consumers would like to observe in upland farms and pastures. Indeed, the potential economic orientation of the economic activity in the pastures was important; $60.7 \%$ of the respondents prefer an agricultural-production orientation of mountain farms, and $33.3 \%$ of the respondents prefer a tourism orientation. Associated with this question is Question 6, which asked respondents to explain their 
preference for the accessibility typology. The group is divided in half between individuals who selected accessibility via footpath, $47.40 \%$, and those who selected accessibility via trail, $47.6 \%$. Interestingly, only $5 \%$ of the sample select accessibility via paved road, suggesting a good sensibility for environmental issues. To further examine the importance of the typology of pasture activities, respondents were asked to express their personal preferences for some potential services offered by upland farms (multiple choice): $74.1 \%$ of the respondents choose "sale of self-production", while $65.3 \%$ of the respondents would like to eat on the farm, including restaurant service, and $52.6 \%$ of the respondents want to spend the night on a farm structure (such as Alpine Huts). Only $4.5 \%$ of the respondents did not want any service in the pastures.

Table 3: Descriptive statistics of the variables.

\begin{tabular}{|c|c|c|c|c|}
\hline Variables & Average & Min & Max & Standard Deviation \\
\hline ACCOM & 3.97 & 1.00 & 5.00 & 0.96 \\
\hline ENV & 4.39 & 1.00 & 5.00 & 0.81 \\
\hline TOWN & 4.43 & 1.00 & 5.00 & 0.75 \\
\hline MULT & 4.07 & 1.00 & 5.00 & 0.96 \\
\hline EVENTS & 3.95 & 1.00 & 5.00 & 1.00 \\
\hline INFRASTR & 4.10 & 1.00 & 5.00 & 0.91 \\
\hline WATER & 3.72 & 1.00 & 5.00 & 1.31 \\
\hline RISK & 3.93 & 1.00 & 5.00 & 1.31 \\
\hline EMPLOY & 4.09 & 1.00 & 5.00 & 1.23 \\
\hline BIOD & 4.05 & 1.00 & 5.00 & 1.30 \\
\hline HERIT & 4.12 & 1.00 & 5.00 & 1.22 \\
\hline AGRICULTURE & 0.61 & 0.00 & 1.00 & 0.49 \\
\hline TOURISM & 0.33 & 0.00 & 1.00 & 0.46 \\
\hline ACTUAL & 0.06 & 0.00 & 1.00 & 0.23 \\
\hline PASTURE & 0.43 & 0.00 & 1.00 & 0.49 \\
\hline FOREST & 0.21 & 0.00 & 1.00 & 0.40 \\
\hline ACTUAL & 0.36 & 0.00 & 1.00 & 0.47 \\
\hline NONE & 0.04 & 0.00 & 1.00 & 0.20 \\
\hline SALE & 0.69 & 0.00 & 1.00 & 0.46 \\
\hline FOOD & 0.61 & 0.00 & 1.00 & 0.49 \\
\hline BED & 0.49 & 0.00 & 1.00 & 0.50 \\
\hline TRAIL & 0.48 & 0.00 & 1.00 & 0.50 \\
\hline ROAD & 0.05 & 0.00 & 1.00 & 0.21 \\
\hline PATH & 0.47 & 0.00 & 1.00 & 0.50 \\
\hline INFO & 2.74 & 1.00 & 5.00 & 1.34 \\
\hline AGE & 37.10 & 14.00 & 72.00 & 17.67 \\
\hline FEM & 0.52 & 0.00 & 1.00 & 0.50 \\
\hline FAM & 3.17 & 0.00 & 20.00 & 1.82 \\
\hline CHILD & 0.44 & 0.00 & 4.00 & 0.75 \\
\hline MIDDLE SCHOOL & & & & 0.41 \\
\hline HIGHSCHOOL & & & & 0.49 \\
\hline DEGREE & & & & 0.44 \\
\hline INCOME & 1965.00 & 350.00 & 4500.00 & 1148.01 \\
\hline WTP & 51.21 & 32.65 & 78.45 & 20.17 \\
\hline
\end{tabular}




\subsection{MCA results}

Variables in Table 4 have been used to perform the MCA analysis. Although MCA was primarily selected to generate a reference system on which to project the hierarchical clustering, observing the arrangement of modalities along the axis generated from the MCA provides interesting insights regarding the associations of respondent's preferences. To implement the MCA, 7 variables were selected from the dataset: three questions directly concerning opinions about issues related to pastures, two questions regarding opinions on valley municipalities, one variable regarding the respondents' education level and one variable concerning the reclassification in two categorical classes of the WTP, a low class, including WTP $<49.3$, and a high class, including WTP $>49.3$, where 49.3 was the median value.
The results of the MCA are shown in figure 2 .

The first two components accounted for $77.30 \%$ of the explained variance: $56.19 \%$ on the first component and $21.11 \%$ for the second component. The variables that mostly contributed to the construction of the first axis in terms of quality were the "economic orientation of pastures" (Q3); the "infrastructure equipment" (INFR), and the "accessibility" (Q6). Moreover, "pastures management" (Q4) shows a relevant contribution to the first component construction (Table 5). The "accessibility" (Q6) is the most important variable for building the second component, together with "economic orientation of pastures" (Q3),"pastures management" (Q4) and "educational degree" (SCHOOL). Modality "well preserved villages" (TOWN 1 ) is excluded from the analysis and only used for illustrative purposes.

Table 4: MCA variables and their descriptions.

\begin{tabular}{|c|c|c|}
\hline $\begin{array}{l}\text { Variable } \\
\text { Name }\end{array}$ & Modalities & Definition \\
\hline TOWN & $\begin{array}{l}\text { TOWN } 1 \\
\text { TOWN } 2 \\
\text { TOWN } 3\end{array}$ & $\begin{array}{l}\text { low importance } \\
\text { medium importance } \\
\text { high importance }\end{array}$ \\
\hline INFR & $\begin{array}{l}\text { INFR } 1 \\
\text { INFR } 2 \\
\text { INFR } 3 \\
\end{array}$ & $\begin{array}{l}\text { low importance } \\
\text { medium importance } \\
\text { high importance }\end{array}$ \\
\hline Q3 & $\begin{array}{l}\text { AGRICULTURE } \\
\text { TOURISM } \\
\text { ACTUAL }\end{array}$ & $\begin{array}{l}\text { agro-productive orientation } \\
\text { touristic orientation } \\
\text { maintenance of actual situation }\end{array}$ \\
\hline Q4 & $\begin{array}{l}\text { PASTURE } \\
\text { FOREST } \\
\text { ACTUAL PASTURE } \\
\end{array}$ & $\begin{array}{l}\text { pasture increase and forest decrease } \\
\text { pasture decrease and forest increase } \\
\text { actual situation }\end{array}$ \\
\hline Q6 & $\begin{array}{l}\text { PATH } \\
\text { ROAD } \\
\text { TRAIL }\end{array}$ & $\begin{array}{l}\text { by path } \\
\text { by road } \\
\text { by trail }\end{array}$ \\
\hline $\mathrm{SCHOOL}$ & $\begin{array}{l}\text { MIDDLE SCHOOL } \\
\text { HIGH SCHOOL } \\
\text { DEGREE }\end{array}$ & $\begin{array}{l}\text { lower secondary school diploma } \\
\text { high school diploma } \\
\text { degree certificate }\end{array}$ \\
\hline WTP & $\begin{array}{l}\text { WTP LOW } \\
\text { WTP HIGH }\end{array}$ & $\begin{array}{l}30,60,15 ; 50,100,20 \\
80,150,40 ; 100,200,50\end{array}$ \\
\hline
\end{tabular}




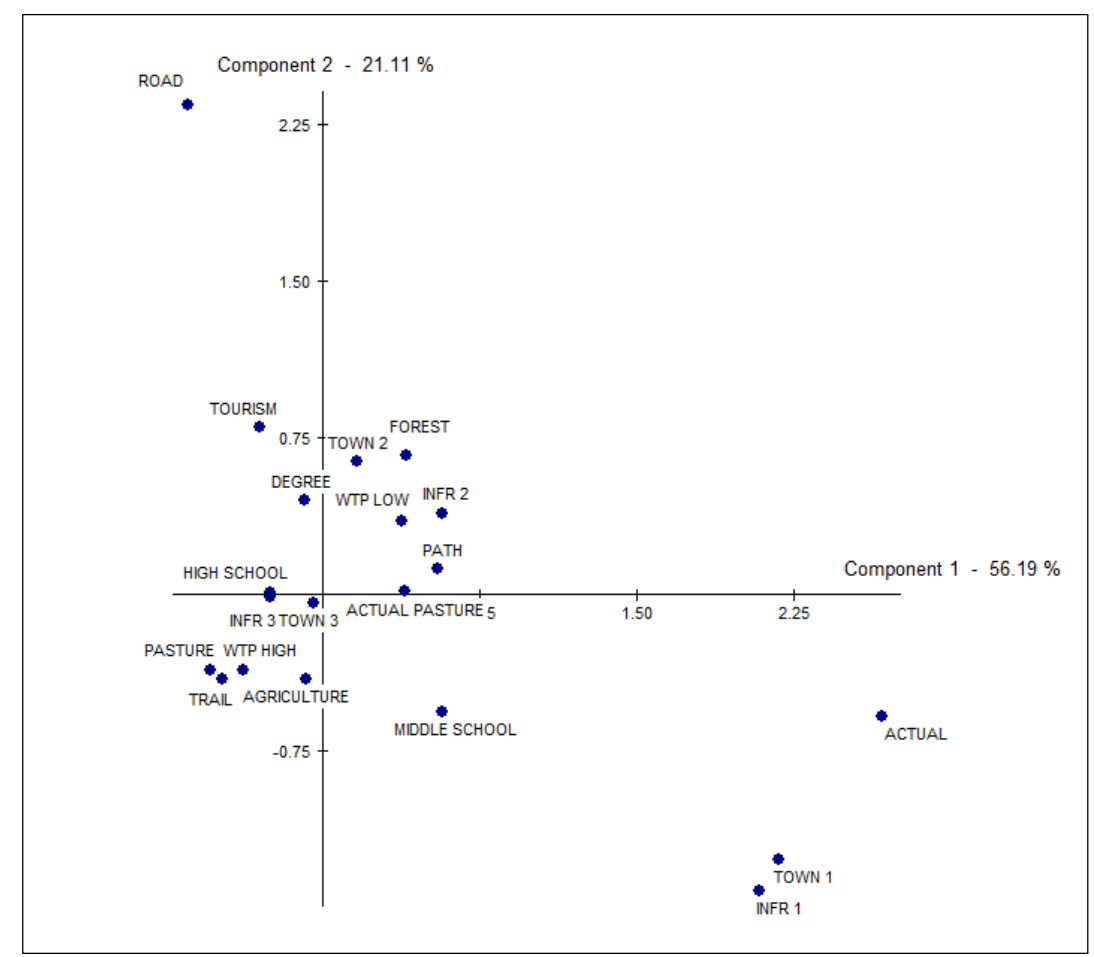

Figure 2: MCA variables divided by the two axes.

Table 5: Contribution of the variables to the MCA first and second components.

\begin{tabular}{|c|c|c|c|c|}
\hline Variable Name & Modalities & Components 1 (\%) & Components 2 (\%) & Total (\%) \\
\hline \multirow{4}{*}{ TOWN } & TOWN 1 & - & - & \multirow{4}{*}{3.0} \\
\hline & TOWN 2 & 0.2 & 2.6 & \\
\hline & TOWN 3 & 0.1 & 0.1 & \\
\hline & TOWN tot & 0.3 & 2.7 & \\
\hline \multirow{4}{*}{ INFR } & INFR 1 & 12.6 & 6.7 & \multirow{4}{*}{28.7} \\
\hline & INFR 2 & 4.1 & 2.1 & \\
\hline & INFR 3 & 3.2 & 0.0 & \\
\hline & INFR tot & 19.9 & 8.8 & \\
\hline \multirow{4}{*}{ Q3 } & ACTUAL & 27.1 & 1.5 & \multirow{4}{*}{55.6} \\
\hline & AGRICULTURE & 0.2 & 8.6 & \\
\hline & TOURISM & 2.1 & 17.1 & \\
\hline & Q3 tot & 29.4 & 26.2 & \\
\hline \multirow{4}{*}{ Q4 } & FOREST & 2.4 & 7.5 & \multirow{4}{*}{26.1} \\
\hline & PASTURE & 8.2 & 4.3 & \\
\hline & ACTUAL PASTURE & 3.9 & 0.0 & \\
\hline & Q4 tot & 14.4 & 11.7 & \\
\hline \multirow{4}{*}{ Q6 } & PATH & 9.9 & 0.6 & \multirow{4}{*}{48.4} \\
\hline & TRAIL & 7.3 & 5.9 & \\
\hline & ROAD & 1.5 & 23.2 & \\
\hline & Q6 tot & 18.7 & 29.7 & \\
\hline \multirow{4}{*}{ SCHOOL } & MIDDLE SCHOOL & 5.6 & 6.2 & \multirow{4}{*}{18.5} \\
\hline & HIGH SCHOOL & 1.9 & 0.0 & \\
\hline & DEGREE & 0.1 & 4.7 & \\
\hline & SCHOOL tot & 7.6 & 10.9 & \\
\hline \multirow{3}{*}{ WTP } & WTP HIGH & 4.9 & 4.9 & \multirow{3}{*}{19.6} \\
\hline & WTP LOW & 4.7 & 5.1 & \\
\hline & WTP tot & 9.6 & 10.0 & \\
\hline
\end{tabular}


The first component derived from the MCA illustrates two opposing concepts of pasture in terms of function and desirable evolutions.

The negative semi axis emphasizes the role of pastures as areas of grazing and agriculture and is associated with trails and a strong consideration for the importance of necessary infrastructures for the municipalities of the valleys. This semi axis also shows high values of WTP for the maintenance of pastures and upland farms and an average level of education ( $\mathrm{HIGH} \mathrm{SCHOOL}$ ). The positive axis represents modalities that reveal a more detached vision of pastures and upland farms, requiring the maintenance of the current state of pastures and a reduction of areas in favour of the expansion of wooded lands. The same semi axis also shows a reluctance to pay for the maintenance of pastures (WTP LOW) and little regard for infrastructures in mountain municipalities. A low level of education is located on the positive semi axis.

The second component also illustrates two opposed concepts of pastures. The positive semi axis concerns the preference for management based on tourism, a road connection on paved roads and the increase of woods and forests over pastures. Remarkably, low values of WTP are located on the same axis. Conversely, the opposing semi axis considers a preference for the management of pastures based on agriculture, a road connection based on trails and an increase of pastures over woods. The calculated WTP associated with the positive side of the second component is high.

The second axis also distinguishes respondents according to their education level, where the positive semi axis includes respondents with university degrees and the negative semi axis accounts for respondents with low education levels.

\subsection{Clusters analysis results}

To define the profiles of rural mountain tourists based on the results from the MCA, a cluster analysis has been performed. Clustering identifies the best solution as a classification of the respondents into three clusters (Table 6).
Table 6: Characterization of clusters by variables.

\begin{tabular}{|c|c|c|c|}
\hline Cluster & Variable & V. Test & $x^{2}$ \\
\hline \multirow{5}{*}{1} & Q4 & 5,99 & 41,33 \\
\hline & Q6 & 5,91 & 40,41 \\
\hline & Q3 & 5,52 & 35,75 \\
\hline & WTP & 5,21 & 28,48 \\
\hline & INFR & 5,02 & 13,36 \\
\hline \multirow{6}{*}{2} & Q3 & 7,2 & 57,66 \\
\hline & Q6 & 6,43 & 47 \\
\hline & Q4 & 5,6 & 36,67 \\
\hline & WTP & 4,24 & 19,34 \\
\hline & SCHOOL & 3,52 & 16,87 \\
\hline & INFR & 2,66 & 11,08 \\
\hline \multirow{7}{*}{3} & Q3 & 11,19 & 131,84 \\
\hline & INFR & 8,3 & 74,93 \\
\hline & SCHOOL & 5,87 & 39,91 \\
\hline & TOWN & 3,6 & 17,47 \\
\hline & WTP & 3,21 & 11,61 \\
\hline & Q6 & 2,93 & 12,77 \\
\hline & Q4 & 2,78 & 11,84 \\
\hline
\end{tabular}

As shown in table 6, the variables that mostly contributed in the cluster formation are "economic orientation of pastures" (Q3), "pastures management" (Q4), and "accessibility" (Q6). The " $Q$ " variables show adequate results in the $\mathrm{V}$-Test and $X^{2}$ (Di Franco 2006).

More weighted variables are directly associated with the individual's idea of pastures and the future desirable development of these lands ("economic orientation of pastures" (Q3), "pastures management" (Q4), and "accessibility" (Q6)), which are better represented in the clustering output. Particularly, these questions refer to the preferred "economic orientation of pastures" (Q3), hypothetical "accessibility" to the upland farms favoured by tourists (Q6) and preferred options with respect to an environment characterized by pastures and meadows rather than forests (Q4). Conversely, the level of education and opinions on valley services are generally of less significance.

A clusters description is presented in table 7. The value "\% CLU/MOD" represents the ratio between 
cluster and modality in percentage, while "\%MOD/ CLU" represents the ratio between modality and cluster in percentage, and "Global" represents how much each modality has been selected by the sample.
The first cluster is the most numerous, with 190 respondents and $51.77 \%$ of the sample; the second cluster represents $35.15 \%$ of the sample (129 persons), and the third cluster represents $13.08 \%$ of the total sample (48 respondents).

Table 7: Cluster description.

\begin{tabular}{|c|c|c|c|c|c|}
\hline Modalities & Variable & V. test & $\%$ CLU/MOD & $\%$ MOD/CLU & \% Global \\
\hline Cluster 1 & & & & & 51,77 \\
\hline PASTURE & Q4 & 9,15 & 79,35 & 64,74 & 42,23 \\
\hline TRAIL & Q6 & 8,75 & 76,02 & 68,42 & 46,59 \\
\hline AGRICULTURE & Q3 & 8,26 & 69,23 & 80,53 & 60,22 \\
\hline WTP HIGH & WTP 2 & 7,68 & 71,98 & 68,95 & 49,59 \\
\hline INFR3 & INFR & 5,03 & 59,01 & 87,89 & 77,11 \\
\hline HIGH SCHOOL & SCHOOL & 2,74 & 59,88 & 52,63 & 45,5 \\
\hline Cluster 2 & & & & & 35,15 \\
\hline TOURISM & Q3 & 9,11 & 67,2 & 65,12 & 34,06 \\
\hline ROAD & Q6 & 6,19 & 100 & 15,5 & 5,45 \\
\hline FOREST & Q4 & 5,41 & 62,03 & 37,98 & 21,53 \\
\hline WTP LOW & WTP 2 & 5,4 & 48,65 & 69,77 & 50,41 \\
\hline DEGREE & SCHOOL & 4,16 & 51,85 & 43,41 & 29,43 \\
\hline Cluster 3 & & & & & 13,08 \\
\hline ACTUAL & Q3 & 9,4 & 100 & 43,75 & 5,72 \\
\hline INFR1 & INFR & 6,76 & 87,5 & 29,17 & 4,36 \\
\hline MIDDLE SCHOOL & $\mathrm{SCHOOL}$ & 6,13 & 33,7 & 64,58 & 25,07 \\
\hline PATH & Q6 & 3,6 & 19,89 & 72,92 & 47,96 \\
\hline WTP LOW & WTP 2 & 3,56 & 19,46 & 75 & 50,41 \\
\hline ACTUAL PASTURE & Q4 & 2,88 & 20,3 & 56,25 & 36,24 \\
\hline
\end{tabular}

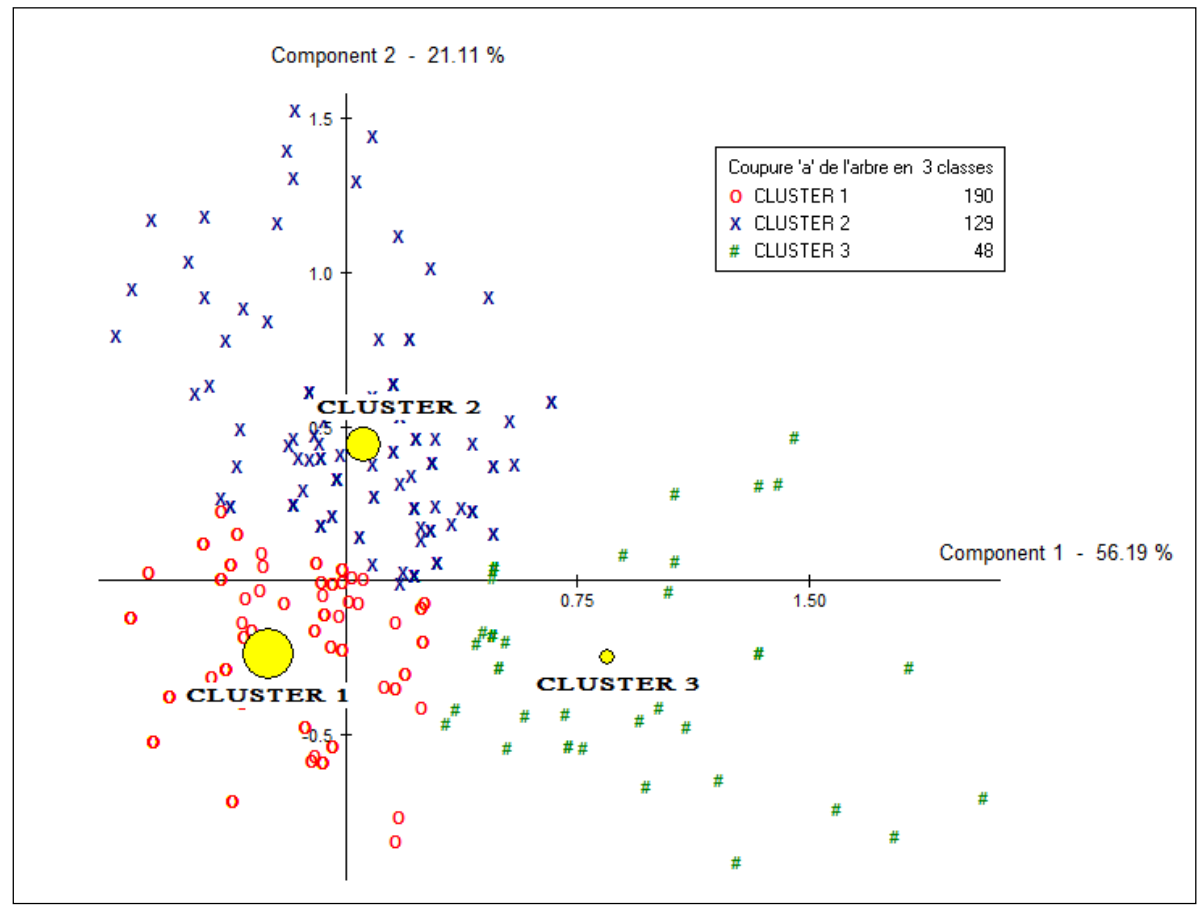

Figure 3: Cluster partitioning 
The description of the clusters (Figure 3 ) is presented in the following paragraphs.

\subsubsection{Agricultural cluster}

The first cluster is named "Agricultural cluster": it includes respondents with a strong preference for the agricultural aspects of pastures and upland farms. Individuals in this group opt for a pasture increase and a subsequent decrease of the woods, only associating these areas with trails and preferring a management model of upland farms based on agriculture rather than on tourism. Furthermore, this cluster is the only one in which respondents declare a high WTP value. This feature delineates individuals who are sensitive to the issues addressed by the survey, i.e., the survival of the high-altitude pastures and farms, since this group combines a high WTP value with the agricultural orientation of the upland farms. However, they emphasize the preference for good infrastructuresto reach the mountain villages to which the pastures and their valleys belong, to avoid the isolation of mountain communities and improve the infrastructural network considered essential. These individuals usually frequent mountains and have a good knowledge of grazing abandonment process; they are persuaded that agriculture may be a tool for allowing the economic subsistence of pastures and the only way to conserve mountain Alpine landscape. This cluster includes people with a medium level of education, that is high school diploma.In this cluster people are willing to pay for the maintenance of mountains with agricultural features, pastures connected by trails and presence of infrastructures in the municipalities of the valleys.

\subsubsection{Reconvertion cluster}

Both the second and the third cluster include respondents who are not willing to pay for the conservation of pastures and upland farms but differ in opinions concerning the desirable typology and evolution of them.

The second cluster is called the "Reconvertion cluster". This group includes respondents who envision the best management model of upland farms and pastures for tourism, providing paved roads for pastures to improve an easy accessibility. They do not mind maintaining the historical hiking trails, but they seem to be more interested in reaching pastures by car, not just by walking.They are not interested in grazing as agricultural activity or landscape maintenance, as they prefer the decreasing of pastures in favour of woods. These respondents seem to love tourist activities in the environment, such as open-air activities and sports, recreational activities and so on; nevertheless, these activities are not necessarily associated with agriculture, but more nature-touristic-oriented. Indeed, respondents included in the second cluster show a low WTP value and although they declare to know the mountain abandonment issue, their revitalization of pastures idea is more and more linked to tourism rather than an agriculture. Finally, they understand Alpine pastures as a mountain place, as a tourist are a similar other mountain tourist area, as for example a ski resort area or a mountain historic town. They frequent pastures and grazing but do not think they should have to pay to conserve them, and they do not believe agriculture is the best choice for mountain development.These individuals agree with the complete reconversion of the pasture structures in tourist areas, where possible, and are not interested in any agricultural activities. The education level among the members of cluster 2 is generally high, as the degree.

\subsubsection{Changeless cluster}

The third cluster is called the "Changeless cluster". It is the less numerous among the three, with 48 respondents, the $13.08 \%$ of the sample. This cluster is constituted by people who are satisfied with the current management of pastures and upland farms, and individuals who do not consider infrastructure to be indispensable for the municipalities of the valley. These individuals show a low education level. Although they declare to prefer actual pasture management, so they like pastures and meadows landscape, they are not willing to pay for the maintenance of traditional extensive agricultureand are not interested in changing policy.

They usually go to the mountain huts, but they want to conserve the current situation, also reaching pastures and huts only with pedestrian paths. Again, in choosing the actual context of "pastures management" (Q3) they declare to prefer a context in which, according to the questionnaire choice "the pasture is left to the progressive abandonment, 
with the advancement of the wood, reduction of the pasture and with degradation of the mountain real estate." These people want to maintain and preserve pasture system without any personal economic investment, that is impossible in the actual situation.

\section{Discussion}

According to the results it is possible to point out some considerations about landscape management in the mountains and possible institutional actions implications.

First, most of the respondents prefers agricultural landscapes rather than forestry landscapes in the mountains (clusters 1 and 3). In fact, despite a low WTP, members of cluster 3 wish for the maintenance of pasture systems and the grazing landscapes. That is, both Cluster 1 "Agricultural cluster"and Cluster 3 "Changeless cluster" express a pasture landscape conservation preference. In mountain areas traditional extensive agriculture substantially contribute to landscape management(Mazzocchi \& Sali 2016): this result confirm findings from previous researchin rural areas, since the main motivations of rural tourists are the contact with nature and the possibility to experience outdoor activities (Bel et al. 2015, MillànVàzquez De La Torre et al. 2013). Moreover, traditional agriculture contribution to landscape can influence tourists' preferences for a destination (Soliva et al. 2008): this is confirmed by the fact that the majority of respondents, included in cluster 1 , are willing to pay for the maintenance of pastures and grazing and they preferred an agricultural management of the pasture system. As for the "Changeless cluster", Bel et al. (2015) in their work on rural France in which they propose a segmentation study based on tourists' rural activities, define a "Passive" cluster similar to our "Changeless cluster", with visitors who are not interested in changing conditions, showing a stable preference behaviour.

Second, the pasture system represents a landscape conservation instrument, and it can assume an economic value as estimated by the WTP of a sample of regular/potential visitors of the mountains. Moreover, since the portion of the sample showing a high WTP prefers pastures to other landscapes, it should be recommended to make investments to maintain the pastureland and its economy. According to Chin \& Lo (2017) natural resources should be conserved to maintain their quality and sustainability over time and the tourism stakeholders, as local communities, public bodies, private enterprises should be working together to environment conservation and to foster an efficient use of natural resources, as pastures and meadows. In addition, our results suggest the existence of different typology of tourists, expressed by the diversity in visitors' motivations between the first (Agricultural cluster) and the second cluster (Reconvertion cluster).

The employment of these resources could lead to an increasing in tourism attractivity of a place, but it is necessary to maintain a balance in the tourists' services an environmental conservation (Chin et al. 2017). Therefore, the indication for public institutions is that the policies should deal with investments that promote tourism in the pasture system and support the extensive agricultural activity of traditional grazing, as suggested form our results on tourists' WTP.

Finally, the demand for agricultural landscapes and nature is increasing among urban population (Van Der Ploeg et al. 2008, Mazzocchi et al. 2014) and ignoring the potentiality of nonmarket goods and functions in policy design can result in substantial losses to society in general (Bateman et al. 2013).

\section{Conclusions}

The present study proposes an experimental method to support the decision-making process of the local authorities for investing public resources in landscape management. The innovation of this work is the segmentation of tourists' sample obtained using MCA and HCA approach, including in each tourist's profile the WTP for the permanence of 
pasture system and landscape. Since the analysis outlines the profile of tourists, it may contribute to a marketing project aimed to communicate and advertise the grazing system and landscape, taking advantage of the demand for tourism in the most efficient way. Moreover, useful guidelinesfor public policies can be drawn based on these results to invest public resources in the aspects of the good best evaluated by tourists. Here, we assessed the preferred options for the management of alpine pastures and landscapes in the Alpine area of Regional Park of Orobie Bergamasche, namely the conversion of huts in multifunctional places, the provision of services required by tourists and the preferred access mode. These aspects and the corresponding levels of WTP might improve the level of provision of public goods and services and allocate more efficiently public resources. In this case study, results suggest that public municipalities should invest in the maintenance and in the renovation of pasture system, considering implementing tourists' services. This methodology is particularly interesting as it may provide support to the management policies of the mountain landscape and the grazing system everywhere, being replicable in any context. Further researches could be focus on the impact of some typologies of agricultural productive activities on tourism sector, for example the role of typical mountain products in supporting mountain agriculture and tourism economy.

\section{References}

Abdi, H. \& Valentin, D. 2007. Multiple Correspondence Analysis. In N. Salkind (Ed.), Encyclopedia of measurement and statistics, (651-657). Thousand Oaks, CA: Sage. DOI: 10.4135/9781412952644. n299

Baronchelli, C. 2016. L'alpeggio come elemento strategico del territorio montano? Un'indagine attraverso Choice Model Approach nel comprensorio delle Orobie Bergamasche. Tesi di Laurea, Università della Montagna, Edolo. http:// www.unimontagna.it/web/uploads/2016/03/ Baronchelli-Corinne-PROTETTO.pdf (Date: 05/12/2018)

Bateman, I. J.; Harwood, A. R.; Mace, G. M.; Watson, R. T.; Abson, D. J.; Andrews, B.; Binner, A.; [...], \& Termansen M. 2013. Bringing ecosystem services into economic decision-making: landuse in the United Kingdom. Science, 5, 341(6141), 45-50. DOI: 10.1126/science.1234379.

Bel, F.; Lacroix, A.; Lyser, S.; Rambonilaza, T. \& Turpin, N. 2015. Domestic demand for tourism in rural areas: Insights from summer stays in three French regions, MPRA 66255. DOI:10.1016/j. tourman.2014.07.020

Bernuès, A.; Rodriguez Ortega, T.; Alfnes, F.; Clemetsen, M.; Eik, L.O. 2015. Quantifying the multifunctionality of fjord and mountain agriculture by means of sociocultural and economic valuation of ecosystem services. Land Use Policy, 48, 170-178. DOI:10.1016/j. landusepol.2015.05.022

Bramwell, B. 1994. Rural tourism and sustainable rural tourism. Journal of Sustainable Tourism, 2, 1-6. DOI:10.1080/09669589409510679

Castellani, V., \& Sala, S. 2009. Sustainable tourism as a factor of local development. Trento: Tangram.

Chin, C.H. \& Lo, M.C. 2017. Rural tourism quality of services: fundamental contributive factors from tourists' perceptions. Asia Pacific Journal of Tourism Research, 1-15. DOI:10.1080/10941665. 2016.1276465

Chrysochou, P.; Gidarakou, I.; Kokkali, P. \& Koutsouris, A. 2006. Rural tourism and local development: The case of the Northern Mt Pelion, Greece. University of Aarhus, selected works. https://works.bepress. com/chrysochou/13/ (Date: 05/12/2018) 
Costa, P. S.; Correia Santos, N.; Pedro Cunha, P.; Jorge Cotter, J.; Sousa, N. 2013. The Use of Multiple Correspondence Analysis to Explore Associations between Categories of Qualitative Variables in Healthy Ageing. Journal of Aging Research. DOI:10.1155/2013/302163

Devesa, M.; Laguna, M. \& Palacios, A. 2010. The role of motivations in tourism satisfaction: empirical evidence in rural tourism. Tourism Management, 31, 547-552. DOI: 10.1016/j. tourman.2009.06.006

Di Franco, G. (2006). Corrispondenze multiple e altre tecniche multivariate per variabili categoriali. Milan: Franco Angeli.

Europarc Federation 1995. European Charter for sustainable tourism in protected areas. http://www.europarc.org/wp-content/ uploads/2015/05/2010-European-Charter-forSustainable-Tourism-in-Protected-Areas.pdf (Date: 05/12/2018)

Frochot, I. 2005. A benefit segmentation of tourists in rural areas: a Scottish perspective. Tourism Management, 26, 345-356. DOI:10.1016/j. tourman.2003.11.016

Garrod, B.; Wornell, R. \& Youell, R. 2006. Reconceptualizing rural resources as countryside capital: the case of rural tourism. Journal of Rural Studies, 22, 117-128. DOI:10.1016/j. jrurstud.2005.08.001

Gios, G.; Goio, I.; Notaro, S. \& Raffaelli, R. 2006. The Value of Natural Resources for Tourism: a Case Study of the Italian Alps. International Journal of Tourism Research, 8, 77-85. DOI: 10.1002/jtr.552

Goio, I. \& Gios, G. 2012. Landscape - Recreational Value: A Resource for Local Development. First Results from a Survey in a Small Mountain Valley (Sinello Valley, Vallarsa, Northern Italy), Landscape Research, 37 (3), 351-364. DOI: 10.1080/01426397.2011.588789
Greenacre, M. \& Hastie, T. 1987. The geometric interpretation of correspondence analysis, Journal of the American Statistical Association, 82, 437-447. DOI:10.1080/01621459.1987.1047 8446

Hjalager, A. M.; Kwiatkowski, G. \& Østervig Larsen, M. 2017. InnovationgapsinScandinavianruraltourism, Scandinavian Journal of Hospitality and Tourism, 1-17. DOI: 10.1080/15022250.2017.1287002

Husson, F.; Josse, J. \& Pagès, J. 2010. Principal component methods - hierarchical clustering - partitional clustering: why would we need to choose for visualizing data? Journal of Aging Research, 12, 1-12.

Jindrová, A. \& Dömeová, L. 2013. Rural tourism services utilization in the Czech Republic. Scientia Agriculturae Bohemica, 44, 256-263. DOI:10.7160/sab.2013.440410

Johnson, R. A. \& Wichern, D. W. 2007. Applied Multivariate Correspondence Analysis. Upper Saddle River, NJ: Prentice Hall.

Keske, C. M. H. \& Mayer, A. 2014. Visitor Willingness to Pay U.S. Forest Service Recreation Fees in New West Rural Mountain Economies. Economic Development Quarterly, 28(1), 87-100. DOI:10.1177/0891242413506744

Lamarque, P. \& Lambin, E. F. 2015. The effectiveness of market-based instruments to foster the conservation of extensive land use: the case of Geographical Indications in the French Alps. Land Use Policy, 42, 706-717. DOI:10.1016/j. landusepol.2014.10.009

Lane B. 1994. What is rural tourism? Journal of Sustainable Tourism, 2, 7-21. DOI:10.1080/09669589409510680 
Lee C., K.; Lee, J.H.; Kim, T., K. \& Mjelde, J.W. 2010. Preferences and willingness to pay for birdwatching tour and interpretive services using a choice experiment. Journal of Sustainable Tourism, 18, 695-708. DOI:10.1080/09669581003602333

Lima, L.; Eusébio, C. \& Kastenholz, E. 2012. Expenditure-Based Segmentation of a Mountain Destination Tourist Market, Journal of Travel \& Tourism Marketing, 29,7, 695-713. DOI: 10.1080/10548408.2012.720155

Lopez Feldman, A. 2012. Introduction to contingent valuation using Stata. Centro de Investigacion y Docencia Economicas. https://mpra.ub.unimuenchen.de/41018/2/intro_CV.pdf (Date: 05/12/2018)

Marangon, F.; Troiano, S.; Tempesta, T. \& Vecchiato, D. 2013. Consumer Behaviour in Rural Tourism. Conjoint analysis of Choice Attributes in the Italian-Slovenian cross-boundary area. Pagri, 3, 77-90.

Mazzocchi, C. \& Sali, G. 2018. Assessing the value of pastoral farming in the Alps using choice experiments: evidence for public policies and management, Journal of Environmental Planning and Management, 1-14. DOI:10.1080/09640568. 2018.1430557

Mazzocchi, C. \& Sali, G. 2016. Sustainability and Competitiveness of Agriculture in Mountain Areas: A Willingness to Pay (WTP) Approach. Sustainability, 8, 343-355. DOI: 10.3390/ su8040343

Mazzocchi, C.; Sali, G. \& Corsi, S. 2014. Agricultural fragility in periurban area: a tool for territorial governance. Scienze Regionali, 13, 3, 51-72. DOI: 10.3280/SCRE2014-003003

MillánVázquez de la Torre, G.; Arjona Fuentes, J. M. \& Amador Hidalgo, L. 2013. Rural Tourism in Natural Parks in Andalusia: An Analysis of the Demand of the Tourist Consumer. International Journal of Humanities and Social Science, 3(1), 52-59.
Molera, L. \& Pilar Albaladejo, I. 2007. Profiling segments of rural tourists of South-Eastern Spain. Tourism management, 28, 757-767. DOI:10.1016/j.tourman.2006.05.006

Molina, J.R.; Rodrìguez y Silva, F. \& Angel Herrera, M. 2016. Integrating economic landscape valuationinto Mediterranean territorial planning. Environmental Science \& Policy 56, 120-128. DOI: 10.1016/j.envsci.2015.11.010

Rathnayake, M. W. R. 2016. Pricing the enjoyment of elephant watching at the Minneriya national park in Sri Lanka: an analysis using CVM. Tourism Management Perspectives, 18, 26-33. DOI: 10.1016/j.tmp.2016.01.002

Soliva, R.; Ronningen, K.; Bella, I.; Bezak, P.; Cooper, T.; Egil Flo, B.; Marty, P. \& Potter, C. (2008). Envisioning upland futures: stakeholders' responses to scenarios for Euriopean mountain landscapes. Journal of Rural Studies, 24, 56-71. DOI: 10.1016/j.jrurstud.2007.04.001

Streifeneder; T., Tappeiner, U.; Ruffini, F. V.; Tappeiner, G. \& Hoffmann, C. 2007. Selected Aspects of Agro-structural Change within the Alps. Journal of Alpine Research, 95, 1-13. DOI: 10.4000/rga.295

Strobl, A.; Teichmann, K. \& Peters, M. 2015. Do mountain tourists demand ecotourism? Examining moderating influences in an Alpine tourism context. Tourism, 63, 383-398.

The International Ecotourism Society (TIES) 2006. TIES Global Ecotourism Fact Sheet. Washington, DC: The International Ecotourism Society (TIES).

Thiene, M. \& Scarpa, R. 2008. Hiking in the Alps: Exploring Substitution Patterns of Hiking Destinations, Tourism Economics (14) 2, 263-282. DOI:10.5367/000000008784460445 
Torquati, B.; Tempesta, T.; Vecchiato, D.; Venanzi, S. \& Paffarini, C. 2017. The Value of Traditonal Rural Landscape and Nature Protected Areas in Tourism Demand: A Study on Agritourists' Preferences.Landscape Online, 53, 1-19. DOI: 10.3097/ LO.201753

Van der Ploeg, J. D.; Van der Broekhuizen, R.; Brunori, G.; Sonnino, R.; Knickel, K.; Tisenkopfs, T. \& Oostindie, H. 2008. Towards a framework for understanding regional rural development. In Van der Ploeg, J.D. \& Marsden, T., Unfolding Webs: The Dynamics of Regional Rural Development. Assen: Royan van Gorcum.

Wedel, M. \& Kamakura, W. 1998. Market segmentation: Conceptual and methodological foundations. Boston: Kluwer Academic Publishers. 